\title{
Biodiversity conservation including uncharismatic species
}

\author{
Joaquin Muñoz
}

Recent papers mention ideas on the topics of biodiversity conservation strategies and priorities (Redford et al. 2003; Lamoreux et al. 2006; Rodríguez et al. 2006), the current status of biodiversity (Loreau et al. 2006), the obligations of conservation biologists regarding management policies (Chapron 2006; Schwartz 2006), and the main threats to biodiversity (including invasive species) (Bawa 2006). I suggest, however, that these articles do not really deal with biodiversity. Rather, they all focus on a few obviously charismatic groups (mammals, birds, some plants, fishes, human culture). Mammals and birds have traditionally been proposed as umbrella or flagship species ("species that needs such large tracts of habitat that saving it will automatically save many other species"-Simberloff 1998), to identify areas suitable as nature reserves (Kerr 1997; Sergio et al. 2005).

In the following I give an example where the strategy of using umbrella species (normally a charismatic large vertebrate) can fail in the conservation of many uncharismatic groups and endemic species. It is recognized that the systematic and conservation status of invertebrates are not well documented, and that yet they are in more severe danger than other groups in nature. As the World Conservation Union (IUCN) indicates: "Most animal species in nature are invertebrates, and the overwhelming majority of threatened species are likely to be invertebrates. But very little has been assessed on this group to infer about its conservation status".

More specifically, aquatic invertebrates merit special interest and attention. One particular problem here is that, following human assisted invasion of an exotic species between continents, a natural method of dispersion by waterbirds (Figuerola et al. 2005) (that may themselves be threatened and protected species) can lead to a rapid invasion of an entire continent. This rapid spread with controversial ecological effects has been reported even in other groups (Phillips and Shine 2004). In the example case, if one protected waterbird species, for instance the flamingo (Phoenicopterus ruber roseus) or the shelduck (Tadorna tadorna), that acts as dispersal 
vector of aquatic invertebrate species, can transport native and invasive species equally well (Green et al. 2005), then the single protected waterbird species may in fact damage conservation efforts as a whole. Some cases have been reported, for instance the invasive species Artemia franciscana (commercially used in aquaculture as food for fishes) in Europe (Green and Figuerola 2005; Amat et al. 2005), which has replaced several populations of native and endemic Mediterranean Artemia species since 1980's, or Daphnia lumholtzi in United States (Green and Figuerola 2005). With this strategy the invertebrate invasive species spread more easily, even "helped" again by humans through the protective strategy of waterbirds.

In examples like these, the goal followed with the umbrella species to conserve certain areas is logical within a regional context and with monitoring species (mainly vertebrates). However, the life history of aquatic invertebrates shows that outcomes can conflict with initial goals.

Another reasons to advocate the consideration of aquatic invertebrate groups in biodiversity conservation exist. On the one hand, there is evidence that most species are not functionally redundant (Tilman and Downing 1994). It is not just charismatic species that are essential to maintain the dynamics of invertebrate populations and, indirectly, of entire aquatic ecosystems (Hurlbert et al. 1983). On the other, conservation strategies based on only a limited number of taxa can fail to provide adequate protection for many other organisms (Prendergast et al. 1993; Simberloff 1998).

It would be regrettable if we lost thousands of species rapidly, simply because they were not charismatic enough for us to pay them attention. The aim of this letter is to call the attention of those readers interested in biodiversity conservation to the question of whether, when we talk about "biodiversity", we are really talking about biodiversity in its widest sense.

Although, in general, conservation has achieved many successes, global biodiversity is still at great risk. We should reflect on whether biodiversity, as is currently considered, will have a good end. We might take into account the importance of too many species in nature to maintain the diversity, ecosystems, and ecological processes stability. I do not mean that the solution to global biodiversity conservation is to consider single or groups of uncharismatic species. I agree with Simberloff (1998) when he says that ecosystem management, often on a landscape scale, is a better solution to problems of single-species management. Although, a large way is need to solve many problems about "ecosystem-based management" definitions (Grumbine 1994; Soule 1994), I suggest that we move quickly to this proposed solution, focusing conservation efforts (researchers and governments) on entire ecosystems including their ecological processes rather than a few groups favored by social, political, or economic interests. And, of course, an exhaustive control regarding the importation and release of exotic species at a global level must be urgently considered.

\section{References}

Amat F, Hontoria F, Ruiz O, Green AJ, Sánchez MI, Figuerola J, Hortas F (2005) The American brine shrimp as an exotic invasive species in the western Mediterranean. Biological Invasions $7: 37-47$

Bawa KS (2006) Conservation requires multiple approaches. Nature 442:744

Chapron G (2006) Scientists are well placed to speak up for biodiversity. Nature 442:627 
Figuerola J, Green AJ, Michot TC (2005) Invertebrate eggs can fly: evidence of waterfowl-mediated gene flow in aquatic invertebrates. The American Naturalist 165(2):274-280

Green AJ, Figuerola J (2005) Recent advances in the study of long distance dispersal of aquatic invertebrates via birds. Diversity and Distributions 11:149-156

Green AJ, Sánchez MI, Amat F, Figuerola J, Hotoria F, Ruiz O, Hortas F (2005) Dispersal of invasive and native brine shrimps Artemia (Anostraca) via waterbirds. Limnology and Oceanography 50(2):737-742

Grumbine RE (1994) What is ecosystem management?. Conservation Biology 8:27-38

Hurlbert SH, Chang CCY (1983) Ornitholimnology: effects of grazing by the Andean flamingo (Phoenicoparrus andinus). Proceedings of the National Academy of Sciences of the United States of America 80:4766-4769

Kerr JT (1997) Species richness, endemism, and the choice of areas for conservation. Conservation Biology 11(5):1094-1100

Lamoreux JF, Morrison JC, Ricketts TH, Olson DM, Dinerstein E, McKnight MW, Shugart HH (2006) Global tests of biodiversity concordance and the importance of endemism. Nature 440:212-214

Loreau M, Oteng-Yeboah A, Arroyo MTK, Babin D, Barbault R, Donogheu M, Gadgil M, Häuser C, Heip C, Larigauderie A, Ma K, Mace G, Mooney HA, Perrings C, Raven P, Sarukhan J, Schei P, Scholes RJ, Watson RT (2006) Diversity without representation. Nature 442:245-246

Phillips BL, Shine R (2004) Adapting to an invasive species: Toxic cane toads induce morphological change in Australian snakes. Proceedings of the National Academy of Sciences of the United States of America 101(49):17150-17155

Prendergast JR, Quinn RM, Lawton JH, Eversham BC, Gibbons DW (1993) Rare species, the coincidence of diversity hotspots and conservation strategies. Nature 365:335-337

Redford KH, Coppolillo P, Sanderson EW, Da Fonseca GAB, Dinerstein E, Groves C, Mace G, Maginnis S, Mittermeier RA, Noss R, Olson D, Robinson JG, Vedder A, Wright M (2003) Mapping the conservation landscape. Conservation Biology 17(1):116-131

Rodríguez JP, Rodríguez-Clakk KM, Oliveira-Miranda MA, Good T, Grajal A (2006) Professional capacity building: the missing agenda in conservation priority setting. Conservation Biology 20(5):1340

Schwartz MW (2006) How conservation scientists can help develop social capital for biodiversity. Conservation Biology 20(5):1550-1552

Sergio F, Newton I, Marchesi L (2005) Top predators and biodiversity. Nature 436:192

Simberloff D (1998) Flagships, umbrellas, and keystones: is single-species management passé in the landscape era? Biological Conservation 83(3):247-257

Soulé ME (1994) Normative conflicts and obscurantism in the definition of ecosystem management. In: Covington WW, DeBano LF (eds) Sustainable ecological systems: implementing an ecological approach to land management. US Department of Agriculture Forest Service, Fort Collins, CO, p 20

Tilman D, Downing A (1994) Biodiversity and stability in grasslands. Nature 367:363-365 